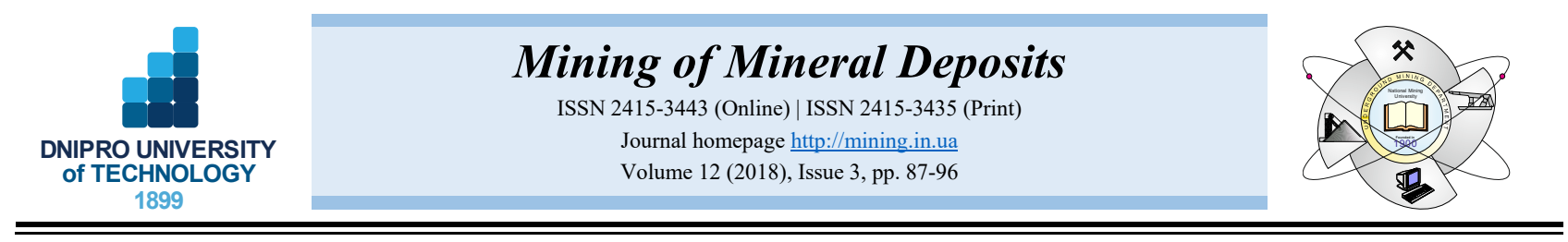

UDC $612.1053+613.6: 669$

https://doi.org/10.15407/mining12.03.087

\title{
ANALYSIS OF THE FACTORS INFLUENCING THE LEVEL OF PROFESSIONAL HEALTH AND THE BIOLOGICAL AGE OF MINERS DURING UNDERGROUND MINING OF COAL SEAMS
}

\author{
S. Cheberiachko ${ }^{1}$, Yu. Cheberiachko ${ }^{1}$, V. Sotskov ${ }^{1 *}$, O. Tytov ${ }^{1}$ \\ ${ }^{1}$ Dnipro University of Technology, Dnipro, Ukraine \\ *Corresponding author: e-mail vadimsockov@gmail.com, tel.+380664837512
}

\begin{abstract}
Purpose. Setting of the work environment of workers at mining enterprises during thin coal seams extraction influence on the character and the rate of their aging by determination of the biological age and estimation of the occupational diseases development risk value.

Methods. The hygienic estimation of the work environment and the occupational diseases development risk value have been determined according to known standard techniques. The approach developed at the Institute of Herontology of National Academy of Medical Sciences of Ukraine has been used for determination of the miners biological age. The aggregate dust load in the air of mining developments has been determined by "AERA" respirator. The following equipment has been used for estimation of the human functional state: "Nissei DS-1902" and "Omron M10-IT" tonometers, "Maniquick MQ-160" infrared contactless thermometer, "VM-150" medical balance. Sampling in the miners breathing zone has been made by "AFA-20" analytical filters. The research results processing has been fulfilled by the method of statistical analysis.

Findings. The exceeding of the maximum permissible rates of adverse factors for miners, such as dust, noise and vibration has been set. The work environment is featured by the constant uncomfortable position of miners bodies and the sufficient loading level. It is determined, that the maximum risk of occupational diseases development is connected with the dust and the static loading factors. The work in such conditions leads to rising of the miners aging rate. Thus, the aging rate is equal to 7 years while having 28.3 years of average age for less than 10 years of service length, and correspondingly 9 years for more than 10 years of service length. The exceeding of the biological age on the calendar age is 15 years in average after the shift.
\end{abstract}

Originality. The character of interrelation between the complex of harmful factors, the occupational diseases development risk and the workers aging rates has been set in the conditions of thin coal seams extraction.

Practical implications. It is necessary to change the working and recreation modes of miners and to guarantee the work for not more than 4 hours with obligatory breaks for rest, in order to enhance the life time of the miners occupied at coal-face works on the thin coal seams extraction.

Keywords: harmful industrial factors, thin coal seams, biological age, miner, hygienic requirements

\section{INTRODUCTION}

Increasing of needs for coal extraction intensification causes many problems in mine fund of Ukraine, leading to its critical condition. Today, the majority of Ukrainian mines have low seam thickness from 0.8 to $1.2 \mathrm{~m}$, with large amount of tectonic violations and weak side rocks (Vivcharenko, 2012; Petlovanyi, Lozynskyi, Saik, \& Sai, 2018). It gives no opportunity to implement modern, high technological, powerful complexes for coal extraction. Every year new seams are developed with depth more than $700 \mathrm{~m}$, also some mines provide works at depth even from 1000 to $1400 \mathrm{~m}$ (Bondarenko, Kovalevs'ka, \& Fomychov, 2012). The length of longwall also increased (Sdvyzhkova, \& Patyńska, 2016). According to (Reynolds, Blackley, Laney, \& Halldin, 2017), Ukraine has about $90 \%$ of gas mines being dangerous on methane releases, about $60 \%$ of mines are characterized by availability of explosive coal dust, the gasdynamic phenomena appear at $42 \%$ of mines, also $23 \%$ of mines are dangerous on coal spontaneous ignition (Bondarenko, Tabachenko, \& Wachowicz, 2010). Often such phenomena appears in faulting zones (Lozynskyi, Saik, Petlovanyi, Sai, \& Malanchuk, 2018).

(C) 2018. S. Cheberiachko, Yu. Cheberiachko, V. Sotskov, O. Tytov. Published by the Dnipro University of Technology on behalf of Mining of Mineral Deposits. This is an Open Access article distributed under the terms of the Creative Commons Attribution License (http://creativecommons.org/licenses/by/4.0/), which permits unrestricted reuse, distribution, and reproduction in any medium, provided the original work is properly cited. 
The most harmful industrial factors at working places for miners are coal dust, noise, vibration and adverse environment (Mukhin, Peredrij, Kharkovenko, 2003; Sokolov \& Udalov, 2017). About $70 \%$ of miners work in the conditions, that don't correspond to sanitary standards. The deceases of dust aetiology are mostly spread in the structure of occupational deceases, as it is noted by the State Statistics Service of Ukraine (Fig. 1).

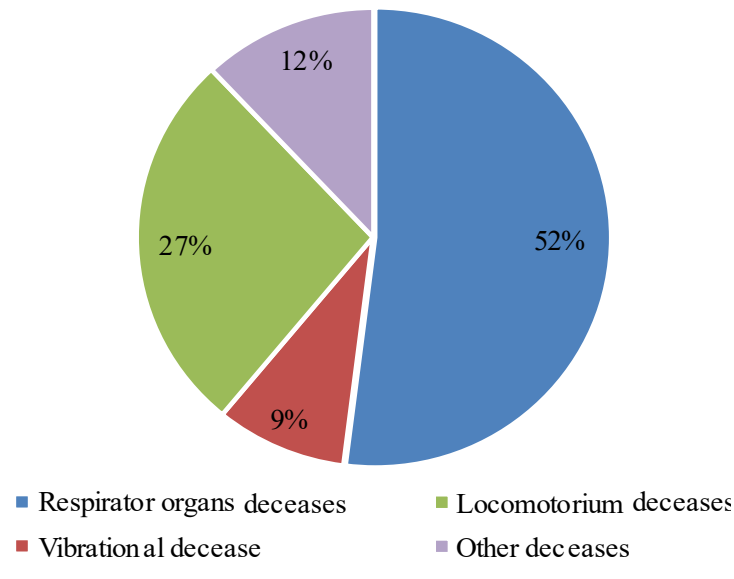

Figure 1. Structure of occupational deceases in 2016

Recently, the registration of less number of occupational deceases (Fig. 2) in Ukraine, is connected first of all with errors of their accounting and control. One of the main reasons is the diagnostics of pathologies on the latest stage (more than $50 \%$ of cases), but not during periodic medical examinations. This can be explained by the part-time employment of workers because of the production volumes decrease, the absence of full and adequate financing of laboratories, the partial completeness or low qualification of medical personnel (Gubernot, Anderson, \& Hunting, 2015; Nandi, Dhatrak, Chaterjee, Dhumne, \& Ingole, 2017).

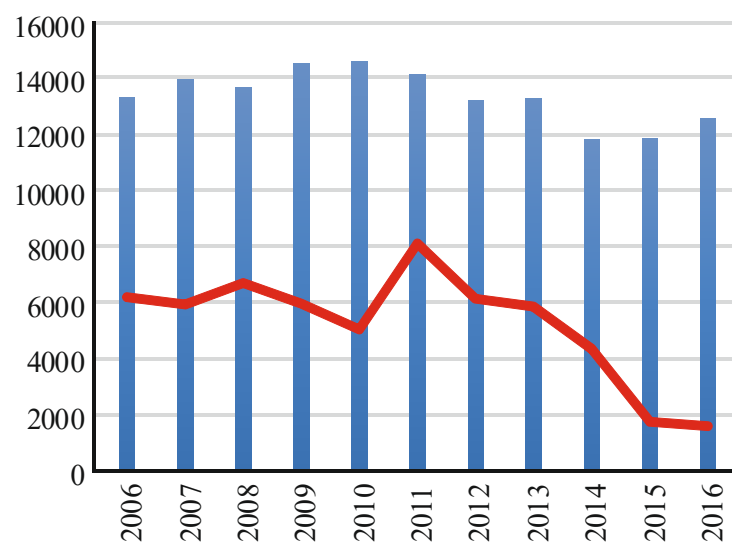

Figure 2. Dynamics of occupational deceases compared to the respiratory deceases $\square$, registered in Ukraine from 2006 to 2016

The goal of coal industry is increasing of mining minerals extraction. It is suggested to reach it mostly by the branch reforming, the modernization of fixed assets and the labor productivity enhancing (Halldin, Wolfe, \& Laney, 2015; Nandi, Dhatrak, Chaterjee, Dhumne, \& Ingole, 2017). Naturally, the latest one must take into consideration the functional state of miners, their working capacity, that is sufficiently depend on the sanitary and hygienic working conditions (Halldin, Wolfe, \& Laney, 2015). The key question is the working safety being influenced by the mining and geological conditions, the stage of industrial processes modernization, the working discipline etc. (Fig. 3) (Chigisova, Ogarkov, \& Maksimov, 2017; Shumate et al., 2017).

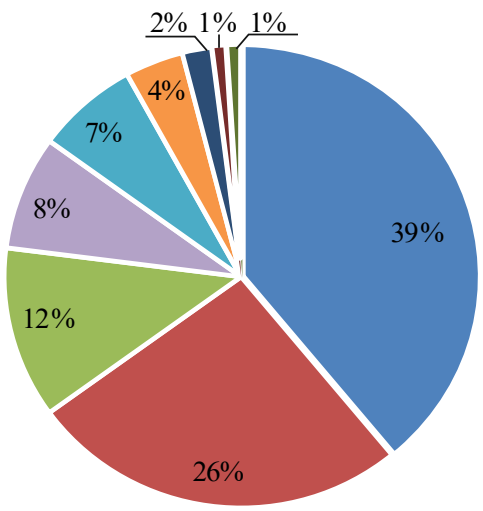

$$
\begin{array}{ll}
\text { - Imperfection of technological } & \text { Imperfection of individual } \\
\text { process } & \text { protective equipment } \\
\text { - Violations of technological } & \text { - Danger of individual } \\
\text { process } & \text { protective equipment } \\
\text { Lack in workplace } & \text { Unsatidfactory production } \\
\text { organization } & \text { organization } \\
\text { - Equipment design lack } & \text { Safety violation } \\
\text { - Others } &
\end{array}
$$

\section{Figure 3. Harmful industrial factors of environment, influen- cing health of miners}

Practice shows, that the largest number of accidents, up to $80 \%$ occurs due to breach of discipline by miners (Bhelkar, Ughade, Thakre, \& Jogdand, 2015). But, there are some cases, when the worker cannot adequately estimate the situation because of presence of many distracting circumstances (noise, dust, increased temperature), its own psychophysiological state, caused by intensity and difficulty of operations fulfilling during working shift. In that case the probability of errors emergence is increased, the possibility "to read" the situation at the working place is reduced, the working discipline is violated (Ishtiaq et al., 2014). That is why the research of miners working conditions is an actual, especially if it allows to reduce the rate of injury and occupational deceases.

Many works are devoted to the problem formulated above. There have been more than 50 of them throughout next several years. The research deals mostly with studying of the injures reasons (Bhattacherjee, 2014; Buessing $\&$ Weil, 2014). The research fulfilled by T.A. Negrei, determining the working conditions for miners and their influence on the injury level is one of interesting works. Also A.M. Tairova contributed much in the injury reasons understanding. She described in the published research results the dependences of the industrial injures rates on the coal extraction volume, the action or inaction of the employer concerning creating of safety working conditions, the operability level of the equipment being used for work with accidents having serious consequences and other factors, based on the mathematical multifactorial models. 
The greatest attention by the mentioned authors is paid to the establishment of the reasons having an impact on the dust content level at working places of the miners, and to the calculation of occupational risks for the miners deterioration in health by influence of industrial dust. There are also works focused on the hearing loss problem solving for the workers at underground spots, and the problems of locomotorium caused by complicated working activity. Let us note the works devoted to the miners working conditions research. For example, the problem of quantitative estimation of influence of the parameters characterizing the miners readiness to technological operations fulfillment and ability of miners to restore forces, on the output of complex mechanized breakage faces, is developed in the works (Shevchenko, 2017; Palei, Karmakar, \& Reddy, 2014; Sanmiquel, Bascompta, Rossell, Anticoi, \& Guash, 2018).

Recently, modern medicine pays more and more attention to such criterion of health estimation as biological age (BA). It characterizes the functional condition of an organism and displays the general "viability" of a person. For this purpose to types of rates of the objective and the subjective estimation are used. The functioning of reserve capabilities of the cardiovascular and the breathing systems with the locomotorium refer to the first group, taking into consideration the age features of examinated persons. The subjective estimation of health according to questioning is put to the second group. This estimation displays in a certain measure the characteristics of the central nervous system (CNS) (Negrey, 2016a; Negrey, 2016b).

It is provided, that the work in conditions of the harmful factors of industrial environment will not only worsen the health state of miners of main professions and will lead to the development of occupational deceases, but will also decrease their life time because of difficult working conditions.

In order to reach this goal, it is necessary to solve the following problems:

- research of working conditions for the miners at mines with coal seams of low thickness;

- determination of the occupational deceases developing risks;

- determination of the miners aging rates.

\section{MATERIALS AND METHODS}

\subsection{Participants}

The hygienic estimation of influence of main adverse industrial factors (vibration, dust, noise, climatic conditions etc.) was fulfilled at working places of the combine operator, their accompanies, the miners of "Stepova" mine of PJSC "DTEK Pavlohradvuhillia". The workers occupied the face contouring, its fastening, conveyor line movement, they took place $5-10 \mathrm{~m}$ upper the combine (Sotskov, Demchenko, Salli, \& Dereviahina, 2017; Sotskov, Podvyhina, Dereviahina, \& Malashkevych, 2018). Also we considered the workers, that carried out the delivery of fastening materials to the longwall, took part in the extension of water and air pipes etc. (Fomichov, Pochepov, Sotskov, \& Mamaikin, 2018; Fomychov \& Sotskov, 2018). This approach allowed to take into consideration the maximum quantity of indus- trial factors influencing the miners health state, having the working 173 longwall of $\mathrm{C}_{6}$ seam off as an example (Fomichov, Sotskov, \& Malykhin, 2014).

10 men of the age from 27 to 45 years and the experience time from 5 to 20 years took part in the experiment. The research had been carried out for half a year since April till September 2017. The main characteristics are shown in Table 1.

Table 1. Characteristics of the experiment participations

\begin{tabular}{cccccc}
\hline $\begin{array}{c}\text { No. of a } \\
\text { participant }\end{array}$ & $\begin{array}{c}\text { Age, } \\
\text { years }\end{array}$ & $\begin{array}{c}\text { Heart } \\
\text { rate }\end{array}$ & $\begin{array}{c}\text { Body } \\
\text { height, } \\
\text { m }\end{array}$ & $\begin{array}{c}\text { Pressure, } \\
\text { mmHg }\end{array}$ & $\begin{array}{c}\text { Working } \\
\text { experience, } \\
\text { years }\end{array}$ \\
\hline 1 & 27 & 65 & 1.78 & $120 / 80$ & 6 \\
2 & 29 & 71 & 1.85 & $125 / 76$ & 7 \\
3 & 26 & 75 & 1.69 & $121 / 87$ & 5 \\
4 & 31 & 69 & 1.91 & $130 / 85$ & 8 \\
5 & 33 & 72 & 1.75 & $130 / 90$ & 10 \\
6 & 35 & 78 & 1.72 & $135 / 90$ & 11 \\
7 & 38 & 90 & 1.63 & $145 / 90$ & 11 \\
8 & 40 & 91 & 1.80 & $140 / 85$ & 16 \\
9 & 43 & 85 & 1.71 & $140 / 90$ & 16 \\
10 & 45 & 73 & 1.87 & $145 / 95$ & 18 \\
\hline
\end{tabular}

\subsection{Organization of research}

The measuring of noise loading by noise sources (NS) at working place of miners was fulfilled in service zones provided by passport of works at the level of $1.5 \mathrm{~m}$ upper the working ground, also at the middle between the ground and the roof of the development, as it is showed in Figure 4, according to DSN 3.3.6-037-99.

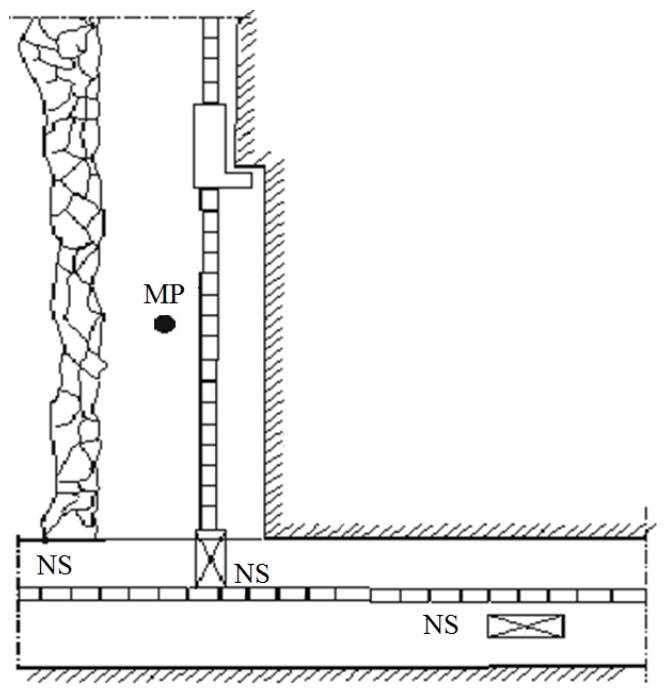

Figure 4. Scheme of the noise sources (NS) and the measuring points (MP) location in mining developments

Not less than 3 measurements of noise loading level were made in each point of "Oktava-101" unit microphone location. The arithmetic average values rounded to integers were took by results of measurements. The repeated measurement was fulfilled if the difference between the largest and the smallest values of the noise loading level indicators in each point was more than $2 \mathrm{dBA}$.

The measurements of the temperature environment parameters and the air content of working space for miners were fulfilled according to the safety rules for coal mines and DSP 3.3.1.095-2002. The places of 
measurements of environment parameters were close to the proceeding and the main air streams of clearing, preparatory and ventilated developments. The measuring points were located at a distance from the wall equal to 0.3 of the development width, and at a height from the ground equal to 0.4 of the development height. The measurements were made in two points from each side of the development. The research was fulfilled by MEC-200A meteometer.

The air sampling for the determination of harmful substances concentration in the developments of "Stepova" mine of PJSC "DTEK Pavlohradvuhillia" was conducted at the distance of $15-20 \mathrm{~m}$ from the place of the air current entrance to the clearing site.

"GKh" gas analyzers were used in a set with indicator pipes for the control of methane, carbon oxide, carbon dioxide and oxygen as ones of the certified in Ukraine. Here, the intaking tube was located towards the air current and was gradually moved zigzag from ground to roof in a vertical plane.

The total concentration of dust in the air of mining developments was determined by "AERA" aspirator. It provided the air sampling in breathing zone of the miners to "AFA-20" analytical filters, with air consumption of 20 liters per minute, also the following weighing at "VLO-200" analytical balance. The time of sampling was measured by "SOPpr-2a-2-10" stop watch. The duration of measurement of the maximum single dust concentration was not less than 30 minutes. The points of sampling are shown in Figure 5.

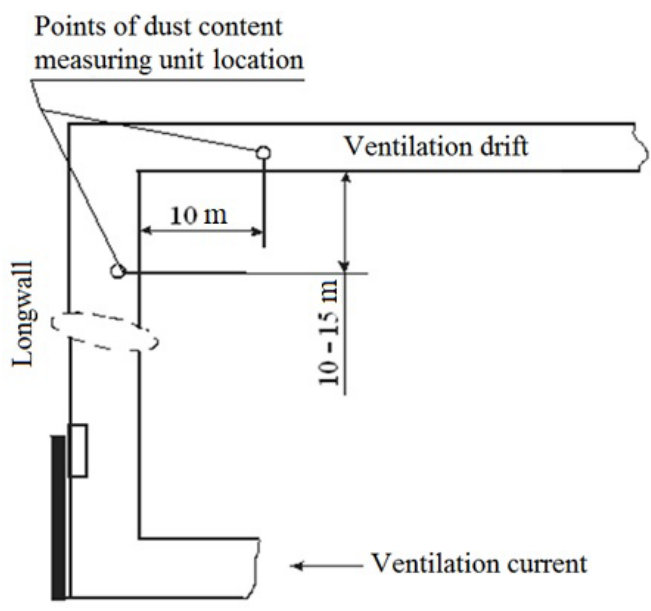

Figure 5. Scheme of location of the constant control meters for the dust content level in the air

The measurement of vibrational loading at the working place was fulfilled by VShV-003-M2 vibrometer according to the DSN 3.3.6-039-99.

The following equipment was used for the estimation of human functional state: "Nissei DS-1902" and "Omron M10-IT" tonometers, "Maniquick MQ-160" infrared contactless thermometer, "VM-150" medical balance. The determination of the miners work severity was carried out according to the recommendations of the Hygienic Classification of Work by indicators of the harmfulness and the danger of the industrial environment factors, the severity and the tension of labor process, approved by the Order of the Ministry of Health of
Ukraine from 08.04.2014 No. 248. The subjective estimation of health (SEH) was conducted by the questionnaire including 27 questions mentioned in the work (Sari, Selcuk, Karpuz, \& Duzgun, 2009). Biological age was determined by the formula (Mahdevari, Shahriar, \& Esfahanipour, 2014):

$$
\begin{aligned}
& B A=26.985+0.215 \cdot S A P-0.149 \cdot B H D- \\
& -0.151 \cdot S B+0.723 \cdot S E H,
\end{aligned}
$$

where:

$S A P$ - the systolic arterial pressure;

$B H D$ - the breath holding duration after deep breath;

$S B$ - the static balancing on the left leg;

$S E H$ - the subjective estimation of health.

The indicators of the body functional state, such as the arterial pressure, the breath holding duration, the static balancing, the self-rating index and the weight were determined at the beginning of the working shift during the obligatory medical examination before work. It was proposed to the miners to control the change of arterial pressure in a lunch break and after work making the corresponding notes. The control of other mentioned parameters was conducted one time per month for the period of half a year, since March till September 2017.

\subsection{Statistical analysis}

The data processing was fulfilled by an application the standard software package Microsoft Office - Excel 2010. The obtained results had the normal distribution law of probabilities. We used mainly Student parametrical models for their analysis. The number of tests was enough to obtain the unbiased estimator of the first two moments, such as the arithmetic average $(M)$ and the average square deviation $(\delta)$. The Student criterion was used for comparison of the quantitative indicators average values for normal distribution of an indication. The significance level of $p<0.05$ with $95 \%$ reliability was considered to be reliable.

\section{RESEARCH RESULTS}

The working mode of 4 shifts, 30 hours per week and 6 hours per shift was approved, according to the sanitary and hygienic characteristic of the miners working conditions. Three shifts of extraction and one shift of repair and preparation $(3 \times 6) E+(1 \times 6) R P$.

The results of the conducted research of working conditions at workplaces in mining developments, the obtained indicators of the adverse industrial factors are given in Table 2 . The information on the miners physical loadings was got by the analysis of the filled cards of working conditions. It is set, that the working conditions refer to the $3^{\text {rd }}$ class of the $2^{\text {nd }}$ or the $3^{\text {rd }}$ harm degree in accordance with Labor Code.

The obtained results show, that mining enterprises were undergone to insignificant modernization of production. Thus, the operator of combine and his assistant maintain high static loading almost three times more than the admissible value during coal-face work. In work (Mahdevari, Shahriar, \& Esfahanipour, 2014), the authors claim, that only $53 \%$ of coal-face works are mechanized and provided with use of serial complexes. 
Table 2. Results of indicators measurement of the adverse industrial factors influencing the miners

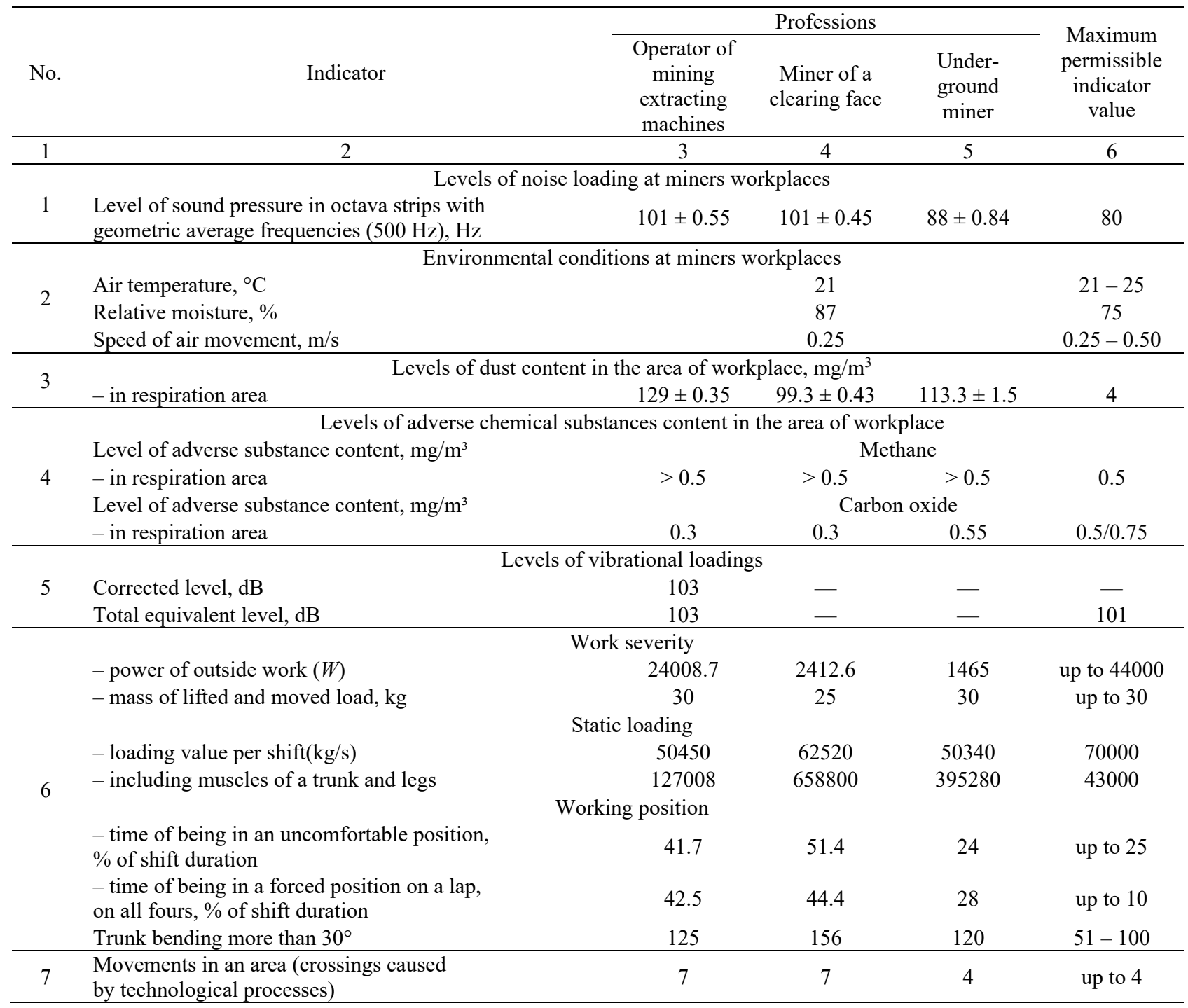

But, the sufficient number of tasks requires for manual labor, takes the largest time part and is characterized as hard work (Liu, Xu, Wu, Yang, \& Wang, 2015). We can fully refer the mentioned above also to the mines with thin coal seams, where execution of labor duties is fulfilled in limited space. The miners stay constantly in an uncomfortable position, on a lap or on all fours. It lasts up to $50 \%$ of a working shift, according to the analysis. Besides, the movement in a breakage face is also carried out in a same way. One more detail is that trunk bending is combined with every working operation on loads carrying, due to the necessity for a miner to bend to a ground in order to lift or to lower the load. The miners of some professions have to fulfill only loads lifting and carrying operations throughout all the shift. In such cases the real number of bends up to $50 \%$ exceeds the admissible value of 100 bends, as one can see from Table 2 . This situation doesn't only contribute to the working ability increasing, but also enhances sufficiently the risk of occupational deceases of locomotorium developing.

It is necessary to determine the risk of deceases developing with help of the obtained data. For this purpose, one should use the most useful for practice method described in international standard OHSAS 18001:2010. The essence is to set the degree of consequences for human organism $(S)$, caused by the danger situation, to determine the danger probability $(P)$ and the frequency of its emergence $(E)$. So, its value is calculated by the formula (Liu, Xu, Wu, Yang, \& Wang, 2015):

$R=S \cdot E \cdot P$,

where:

$R$ - the risk;

$S$ - the degree of consequences;

$E$ - the frequency of its emergence;

$P$ - the danger probability.

The frequency of the danger situation emergence is varied from 0 to 10 units. The probability of the danger emergence and the degree of consequences are rated in the three different levels (low, average, high). The combination of the mentioned factors classifies the professional risk by the degree of acceptability (gravity) to five main groups: from the minimum value 1 (insignificant risk) to the maximum value 5 (inadmissible risk). The simplicity and the possibility to involve the direct participants of industrial process may be considered as the advantages of this method. Besides, the presented result in a quantitative form allows to obtain the sharp criteria of acceptability (gravity) for occupational risks, also to estimate the corresponding recommendations concerning their elimination. 
The probability of the occupational deceases developing risks, caused by the industrial danger factors, is rated based on their action duration and emergence frequency. In another way, they are compared with results of the maximum permissible values measurements. The results of the risk values calculation for the above mentioned working conditions (Table 2) are presented in Tables 3 and 4 .

\begin{tabular}{|c|c|c|c|}
\hline & \multicolumn{3}{|c|}{ Danger factor } \\
\hline & Working position & Static loading & Trunk bending \\
\hline Situation description & $\begin{array}{l}\text { Being in uncomfortable working } \\
\text { position (on all fours, on a lap etc. - } \\
51 \% \text { of shift duration (rate is } \\
\text { up to } 25 \% \text { of shift duration) }\end{array}$ & $\begin{array}{c}\text { Loading value per shift }(\mathrm{kg} / \mathrm{s}) \\
\text { while load retention by } \\
\text { muscles of trunk and legs } \\
(\text { rate is } 43000 \mathrm{~kg} / \mathrm{s})\end{array}$ & $\begin{array}{l}\text { Trunk bends } 101-200 \text { times } \\
\text { (rate is } 51-100 \text { times) }\end{array}$ \\
\hline Consequences & Average & Hard & Light \\
\hline Risk probability & High & High & High \\
\hline Risk level & Sufficient 4 & Inadmissible 5 & Moderate 3 \\
\hline
\end{tabular}

Table 4. Risk rating on the adverse factors influence

\begin{tabular}{|c|c|c|c|c|}
\hline & \multicolumn{4}{|c|}{ Danger factor } \\
\hline & Vibration & Industrial noise & $\begin{array}{l}\text { Air temperature } \\
\text { in working area }\end{array}$ & Dust \\
\hline Situation description & $\begin{array}{c}\text { Total action duration } \\
\text { of vibration per shift is } \\
151 \text { minutes for excess } \\
\text { of maximum permissible } \\
\text { level (MPL) on } 6 \mathrm{~dB} \text { (rate } \\
\text { excess on } 30 \text { minutes) }\end{array}$ & $\begin{array}{l}\text { Total action duration } \\
\text { of noise per shift is } \\
340 \text { minutes (excess of } \\
\text { maximum permissible } \\
\text { level (MPL) on } 20 \mathrm{dBA} \text { ) }\end{array}$ & $\begin{array}{c}\text { Air temperature } \\
\text { in underground } \\
\text { development is } 21^{\circ} \mathrm{C}\end{array}$ & $\begin{array}{l}\text { Danger class } 4 \text { is } \\
120 \mathrm{mg} / \mathrm{m}^{3} \text { (excess of } \\
\text { threshold limit value } \\
\text { (TLV) in } 30 \text { times) }\end{array}$ \\
\hline Consequences & Average & Average & Light & Hard \\
\hline Risk probability & High & High & Low & High \\
\hline Risk level & Sufficient 4 & Sufficient 4 & Insufficient 1 & Inadmissible 5 \\
\hline
\end{tabular}

The analysis of the fulfilled calculation has shown, that the action of miner dust and the static loading refer to inadmissible risk. We suppose, concerning the last one, that the workers of the basic professions are manually occupied for more than 5 hours per shift, that makes correspondingly $90 \%$ of the shift duration. Here, the average level of their energy consumption per shift is high and equal to $4.4-6.4 \mathrm{kcal} / \mathrm{min}$ (Sari, Duzgun, Karpuz, \& Selcuk, 2004).

It should be noted, that adverse action of the coal dust and the noise loading, having sufficient risk level, are added to the influence of hard manual labor. The need arises, for estimation of the general health state of miners, working under action of the mentioned above adverse factors, taking into consideration their cumulative effect. The most acceptable method for such an estimation is the calculation of biological age and its further influence on the degree of individual aging.

The biological age characterizes the organism functional state and displays the general "viability" of a person by certain indicators of the objective and the subjective estimations of functioning and reserve abilities of the cardiovascular and the respiratory systems, the CNS, the locomotorium, when taking into consideration the age peculiarities of the examined persons (Browne, 1973). It is proved, that there is a close correlation between the age and the deceases. The abilities to adaptation of an organism have been decreasing as a result of aging, making weak points in its selfregulation system and simplifying the development of deceases. Aging processes "reduce" the organism reserve abilities and lead to the development of pathology. In such cases, the technique of the aging degree estimation, based on the determination of biological age, is one of the most reliable and acceptable.

The result of the biological age calculation is based on determination of the arterial pressure and the static balance indicators before the shift and after it. It is supposed, that the breath holding delay and the self-rating of health level index don't change quickly, so they have been checked only one time at the beginning of the experiment. The results are given in Table 5. The fulfilled calculation data specify on increasing of indicators of the systolic arterial pressure and the heart rate $(H R)$, also decreasing of the static balancing time. The indicators of the basic physiological tests are shown in Table 6.

Table 5. Calculated average values for indicators of the miners functional state at the beginning and at the end of a shift

\begin{tabular}{lcccc}
\hline \multicolumn{1}{c}{ Indicators } & Before shift & After shift & Student $\tau$-criterion & Confidence interval $(p)$ \\
\hline$S A P, \mathrm{mmHg}$ & $133.1 \pm 0.96$ & $137.64 \pm 0.94$ & -2.9954 & 0.047 \\
Pressure, mmHg & $86.8 \pm 0.81$ & $91.64 \pm 0.40$ & -1.544 & 0.240 \\
$H R$, beats/min & $76.9 \pm 0.46$ & $89.3 \pm 0.51$ & -9.2870 & 0.0002 \\
$S B, \mathrm{~s}$ & $45.5 \pm 3.46$ & $17.6 \pm 0.61$ & -2.954 & 0.512 \\
$B H D, \mathrm{~s}$ & $53.6 \pm 0.81$ & $34.5 \pm 0.91$ & -1.63 & 0.341 \\
\hline \multicolumn{4}{c}{ Biological age } \\
\hline Service length less than 10 years & 35.5 & 44.1 & - & - \\
Service length more than 10 years & 46.6 & 53.5 & - & - \\
\hline
\end{tabular}


Table 6. Indicators of basic physiological tests of miners after work day

\begin{tabular}{cccccccc}
\hline $\begin{array}{c}\text { Service length, } \\
\text { years }\end{array}$ & $\begin{array}{c}\text { Number } \\
\text { of miners }\end{array}$ & Average age, years & $\begin{array}{c}S A P, \\
\mathrm{mmHg}\end{array}$ & $B H D, \mathrm{~s}$ & SB, s & SEH, points & BA, years \\
\hline $5-10$ & 4 & $28.3 \pm 0.9$ & $128.5 \pm 2.1$ & $43.6 \pm 0.7$ & $48.9 \pm 1.5$ & $4.4 \pm 0.6$ & $44.1 \pm 1.1$ \\
$10-15$ & 3 & $35.3 \pm 1.4$ & $138.6 \pm 3.2$ & $35.3 \pm 1.4$ & $41.3 \pm 1.1$ & $7.1 \pm 0.7$ & $50.8 \pm 0.9$ \\
$>15$ & 3 & $42.4 \pm 0.7$ & $145.6 \pm 2.5$ & $25.2 \pm 0.9$ & $23.6 \pm 3.3$ & $8.7 \pm 0.5$ & $57.1 \pm 0.9$ \\
\hline
\end{tabular}

The calculated biological age after the shift has been about $15-16$ years, but it was sufficiently different before the shift. Thus, the aging rate has been 7 years while having 28.3 years of average age for less than 10 years of service length, and correspondingly 9 years for more than 10 years of service length. So, the workers with different service length (from 5 to 10 years and more than 10 years) have different aging rate values. It comes to conclusion, that the occupational activity influences the aging rate and displays in some way their health state. As a result, the biological age after the shift exceeds the calendar age in average for 15 years.

\section{DISCUSSION}

The obtained result may be explained by the fact, that the miners working conditions feature high degree of physical loading. The human organism doesn't manage to restore fully after the working shift being influenced also by another adverse factors like the dust and the noise. We will use the calculation results of the heart rate dependence on the energy consumption during the physiotherapy exercises occupation of people (Sari, Duzgun, Karpuz, $\&$ Selcuk, 2004), in order to prove this conclusion:

$$
N=0.149 \cdot H R-10.68 \text {. }
$$

The same formulas were obtained in the work by T.A. Negrey, based on the results of corresponding research (Negrey, 2016a; Negrey, 2016b):

$$
N=0.125 \cdot H R-7.526 \text {. }
$$

We can see, that the heart rate value for miners are higher, than for athletes. The calculated difference in energy consumption for the exercises with same loadings can be just explained by adverse influence of the miners environment.

The borders between areas of the heart rate at rest and the maximum value, when the worker is able to fulfill his labor duties, are given in Table 7.

Table 7. The results of the human organism energy consumption dependence on the heart rate

\begin{tabular}{ccc}
\hline \multirow{2}{*}{$\begin{array}{c}H R, \\
\text { beats/min }\end{array}$} & \multicolumn{2}{c}{$\begin{array}{c}\text { Energy consumption } \\
\text { of human organism, kcal/min }\end{array}$} \\
\cline { 2 - 3 } & $\begin{array}{c}\text { during physiotherapy } \\
\text { exercises }\end{array}$ & $\begin{array}{c}\text { during miners } \\
\text { work }\end{array}$ \\
\hline 80 & 1.24 & 2.47 \\
90 & 2.73 & 3.72 \\
100 & 4.22 & 4.97 \\
120 & 7.20 & 7.47 \\
\hline
\end{tabular}

The heart rate at rest depends on the age, the male, the person's way of life, and makes $60-70$ beats per minute for most of adult healthy people (Page, 2009). The heart rate can reach the value of $H R=180$ and even more beats per minute during physical loadings. While exceeding $H R_{\max }$, the person's productivity decreases, because, since that moment, the pulmonary ventilation rises faster than the work output. The zones are shown, that refer to different categories of work severity (from the light to very hard ones (Paul \& Maiti, 2007)).

The inhaling of harmful aerosols is one more reason for the miners premature aging. The most probable explanation is reaction of the organism to the stress. It is pointed in works of A.F. Verbov, that long, lasted for many years influence of aerosols on the worker's organism can be compared with the chronic stress state or the stage of general adaptation syndrome by H. Sel'ye. It is known, that every stress influence, also connected with adverse occupational conditions, intensifies the aging process. Besides, the pneumoconiosis development during dust deceases can be considered as one of the symptoms of the organism premature aging.

This situation leads to the development of new deceases or to the aggravating of available chronic ones, that accelerate the aging. It characterizes by displays of hypertension, chronic coronary heart decease and stomach ulcer. The direct dependence of the premature aging on the working conditions is traced, if we take into consideration the complaints of miners to doctors. The analysis of biological age testing results has allowed to allocate from the set of physiological indicators the main factor, forming the biological age. This is the arterial pressure (systolic and diastolic) for men. It is found out by the analysis of disability papers, that hypertension takes one of the first places among deceases.

Noise and vibration belong to adverse factors influencing the miners health. The fulfilled research has shown, that the miners work in the conditions of moderate risk for development of occupational decease like sencorineural hearing loss. But, the hearing loss will reach $12 \mathrm{~dB}$ for $50 \%$ of people just in 5 years of such work without using of individual protection equipment of hearing organs (IPEHO). The only real measure to protect from noise is the time limitation for being in danger area.

So, it is necessary to decrease the influence of adverse factors, in order to increase the life expectancy. It is recommended to modify the modes of work and recreation. The working time should not exceed 4 hours per day with obligatory rest pauses.

\section{CONCLUSIONS}

The fulfilled analysis of working conditions proves, that the work in the conditions of industrial environment adverse factors influence not only worsen the miners health, but also contributes to their life time decreasing. It is due to reduction of the organism reserve abilities caused by accelerated wear of the cardiovascular system. The high degree of nervous and emotional tension, endured by miners, influences the discrepancy of biological age to the calendar one. It refers also to the overloading of muscles during fulfilling physical work, making the same effect on 
the cardiovascular system. The review of lust publications, together with measuring results of the adverse industrial factors influence on the workers health and their biological age, confirm the actuality of the research goal and the need for more detailed analysis of the miners occupational deceases risks. The main sense of the research results is determination of interrelation between the adverse factors complex, influencing the miners health, and the workers aging rates. It means to determine the acceptable limit of the occupational deceases development probability.

\section{ACKNOWLEDGEMENTS}

The research is carried out within the framework of scientific topics GP-497 (No. 0117U006753) "Resourcesaving geotechnical and hydrodynamic parametrization of the extraction of low-capacity mineral raw materials in an technogenically loaded environment", financed by the state budget of Ukraine.

\section{REFERENCES}

Bhattacherjee, A. (2014). Associations of some individual and occupational factors with accidents of dumper operators in coal mines in India. Journal of Ergonomics, (S5), 1-4. https://doi.org/10.4172/2165-7556.s5-001

Bhelkar, S.M., Ughade, S.N., Thakre, S., \& Jogdand, G. (2015). A comparative study of morbid conditions amongst opencast and underground coal miners. Journal of Evolution of Medical and Dental Sciences, 04(07), 1132-1137. https://doi.org/10.14260/jemds/2015/159

Bondarenko, V., Kovalevs'ka, I., \& Fomychov, V. (2012), Features of carrying out experiment using finite-element methodat multivariate calculation of mine massif - combined support system. Geomechanical Processes During Underground Mining, 7-13. https://doi.org/10.1201/b13157-3

Bondarenko, V., Tabachenko, M., \& Wachowicz, J. (2010). Possibility of production complex of sufficient gasses in Ukraine. New Techniques and Technologies in Mining, 113-119. https://doi.org/10.1201/b11329-19

Browne, R.C. (1973). Safety and health at work: The Robens Report. Occupational and Environmental Medicine, 30(1), 87-91. https://doi.org/10.1136/oem.30.1.87

Buessing, M., \& Weil, D. (2014). Impact of contracting on occupational injuries and fatalities in underground coal mining. Boston, United States: Boston University.

Chigisova, A.N., Ogarkov, M.Y., \& Maksimov, S.A. (2017). Risk of arterial hypertension in workers employed at coalmining enterprises: Social and hygienic assessment. Health Risk Analysis, (3), 76-82. https://doi.org/10.21668/health.risk/2017.3.09.eng

Fomichov, V., Sotskov, V., \& Malykhin, A. (2014). Determination and analysis of the acceptable benchmark changes of the stress strain state of frame and bolt fastening elements of dismantling drift when approaching a working face. Naukovyi Visnyk Natsionalnoho Hirnychoho Universytetu, (1), 22-26.

Fomichov, V., Pochepov, V., Sotskov, V., \& Mamaikin, O. (2018). Formation of a calculation model determining optimal rate of stoping face movement with a large deformation of a rock massif. ARPN Journal of Engineering and Applied Sciences, 13(7), 2381-2389.

Fomychov, V., \& Sotskov, V. (2018). Determination of parameters of non-uniform fractured rock massif in computing experiment. Journal of Geology, Geography and Geoeco$\log y, 26(1), 26-32$.

https://doi.org/10.15421/111803
Gubernot, D.M., Anderson, G.B., \& Hunting, K.L. (2015). Characterizing occupational heat-related mortality in the United States, 2000 - 2010: An analysis using the census of fatal occupational injuries database. American Journal of Industrial Medicine, 58(2), 203-211. https://doi.org/10.1002/ajim.22381

Halldin, C.N., Wolfe, A.L., \& Laney, A.S. (2015). Comparative respiratory morbidity of former and current US coal miners. American Journal of Public Health, 105(12), 2576-2577. https://doi.org/10.2105/ajph.2015.302897

Ishtiaq, M., Jehan, N., Rehman, Z.U., Sardar, M., Israr, M., \& Khan, G.S. (2014). Factors associated with occupational injuries in coal miners. Journal of Medical Sciences, 22(1), 21-24.

Liu, L., Xu, X., Wu, H., Yang, Y., \& Wang, L. (2015). Associations of psychological capital, demographic and occupational factors with cigarette smoking among Chinese underground coal miners. BMC Public Health, 15(1), 20-30. https://doi.org/10.1186/s12889-015-1349-6

Lozynskyi, V., Saik, P., Petlovanyi, M., Sai, K., \& Malanchuk, Y. (2018). Analytical research of the stress-deformed state in the rock massif around faulting. International Journal of Engineering Research in Africa, (35), 77-88. https://doi.org/10.4028/www.scientific.net/jera.35.77

Mahdevari, S., Shahriar, K., \& Esfahanipour, A. (2014). Human health and safety risks management in underground coal mines using fuzzy TOPSIS. Science of The Total Environment, (488-489), 85-99.

https://doi.org/10.1016/j.scitotenv.2014.04.076

Mukhin, V.V., $\quad$ Peredrij, G.S., Kharkovenko, N.M. (2003). Level, structure and dynamics of combined occupational diseases among coal miners of Donetsk region. Meditsina Truda i Promyshlennaya Ekologiya, (9), 11-13.

Nandi, S., Dhatrak, S.V., Chaterjee, D.M., Dhumne, U.L., \& Ingole, S.V. (2017). A study on morbidity profile of lignite miners in western India. International Journal of Occupational Safety and Health, 5(1), 14-16. https://doi.org/10.3126/ijosh.v5i1.16630

Negrey, T.A. (2016a). O bezopastnosti truda gornorabochikh pri vypolnenii osnovnykh proizvodstvennykh operatsiy. Visti Donetskoho Hirnychoho Instytutu, 1(38), 84-94.

Negrey, T.A. (2016b). Issledovanie usloviy truda shakhterov pri vypolnenii osnovnykh proizvodstvennykh protsesov. Visti Donetskoho Hirnychoho Instytutu, 2(39), 108-116.

Page, K. (2009). Blood on the coal: the effect of organizational size and differentiation on coal mine accidents. Journal of Safety Research, 40(2), 85-95. https://doi.org/10.1016/j.jsr.2008.12.007

Palei, S.K., Karmakar, N.C., \& Reddy, R.S.M. (2014). Effects of demography and occupational traits on consequence of injury of underground coal miners. 2014 IEEE International Conference on Industrial Engineering and Engineering Management, 1260-1264. https://doi.org/10.1109/ieem.2014.7058840

Paul, P.S., \& Maiti, J. (2007). The role of behavioral factors on safety management in underground mines. Safety Science, 45(4), 449-471. https://doi.org/10.1016/j.ssci.2006.07.006

Petlovanyi, M.V., Lozynskyi, V.H., Saik, P.B., \& Sai, K.S. (2018). Modern experience of low-coal seams underground mining in Ukraine. International Journal of Mining Science and Technology. Article in press. https://doi.org/10.1016/j.ijmst.2018.05.014

Reynolds, L.E., Blackley, D.J., Laney, A.S., \& Halldin, C.N. (2017). Respiratory morbidity among US coal miners in states outside of central Appalachia. American Journal of Industrial Medicine, 60(6), 513-517. https://doi.org/10.1002/ajim.22727

Sanmiquel, L., Bascompta, M., Rossell, J.M., Anticoi, H., \& Guash, E. (2018). Analysis of occupational accidents in 
underground and surface mining in Spain using data mining techniques. International Journal of Environmental Research and Public Health, 15(3), 462-472. https://doi.org/10.3390/ijerph15030462

Sari, M., Duzgun, H.S.B., Karpuz, C., \& Selcuk, A.S. (2004). Accident analysis of two Turkish underground coal mines. Safety Science, 42(8), 675-690. https://doi.org/10.1016/j.ssci.2003.11.002

Sari, M., Selcuk, A.S., Karpuz, C., \& Duzgun, H.S.B. (2009). Stochastic modeling of accident risks associated with an underground coal mine in Turkey. Safety Science, 47(1), 78-87. https://doi.org/10.1016/j.ssci.2007.12.004

Sdvyzhkova, O., \& Patyńska, R. (2016). Effect of increasing mining rate on longwall coal mining - Western donbass case study. Studia Geotechnica et Mechanica, 38(1), 91-98. https://doi.org/10.1515/sgem-2016-0010

Shevchenko, V.G. (2017). Research on the influence of miners' energy expenditure on coal mining efficiency. Scientific Bulletin of National Mining University, (3), 140-146.

Shumate, A.M., Yeoman, K., Victoroff, T., Evans, K., Karr, R., Sanchez, T., \& Laney, A.S. (2017). Morbidity and health risk factors among New Mexico miners. Journal of Occupational and Environmental Medicine, 59(8), 789-794. https://doi.org/10.1097/jom.0000000000001078

Sokolov, V.A., \& Udalov, I.V. (2017). Mineral and raw material base of agronomical ore in Kharkiv region. Visnyk of V.N. Karazin Kharkiv National University - Series Geology Geography Ecology, (47), 206-210. https://doi.org/10.26565/2410-7360-2017-47-27

Sotskov, V., Demchenko, Yu., Salli, S., \& Dereviahina, N. (2017). Optimization of parameters of overworked mining gallery support while carrying out long-wall face workings. Naukovyi Visnyk Natsionalnoho Hirnychoho Universytetu, (6), 34-40.

Sotskov, V., Podvyhina, O., Dereviahina, N., \& Malashkevych, D. (2018). Substantiating the criteria for applying selective excavation of coal deposits in the Western Donbass. Journal of Geology, Geography and Geoecology, 26(1), 158-164. https://doi.org/10.15421/111817

Vivcharenko, O. (2012). Development of coal industry of Ukraine in the context of contemporary challenges. Geomechanical Processes During Underground Mining, 1-5. https://doi.org/10.1201/b13157-2

\title{
АНАЛІЗ ЧИННИКІВ, ЩО ВПЛИВАЮТЬ НА СТАН ПРОФЕСІЙНОГО ЗДОРОВ'Я ТА БІОЛОГІЧНОГО ВІКУ ГІРНИКІВ ПРИ ПІДЗЕМНІЙ РОЗРОБЦІ ВУГІЛЬНИХ ПЛАСТІВ
}

\author{
С. Чеберячко, Ю. Чеберячко, В. Соцков, О. Титов
}

Мета. Встановлення впливу умов праці робітників гірничих підприємств при розробці тонких вугільних пластів на характер і темп їх старіння шляхом визначення біологічного віку та оцінки величини ризику виникнення професійних захворювань.

Методика. Гігієнічну оцінку умов праці та величину ризику виникнення професійних захворювань визначали за відомими нормативними методиками. Для розрахунку біологічного віку гірників був використаний підхід, розроблений в Інституті геронтології Академії медичних наук України. Загальну концентрацію пилу в повітрі гірничих виробок визначали за допомогою аспіратора “АЕРА”. Для оцінки функціонального стану людини використана наступна техніка: тонометр "Nissei DS-1902” та “Omron M10-IT”, інфрачервоний безконтактний термометр “Maniquick MQ-160”, ваги медичні “ВМ-150”. Відбір проб у зоні дихання гірників здійснювався аналітичними фільтрами “АФА-20”. Обробка результатів досліджень проводилась за допомогою методу статистичного аналізу.

Результати. Встановлено перевищення гранично допустимих показників несприятливих факторів для гірників - пилу, шуму та вібрації. Умови праці характеризуються постійним незручним положенням тіла робітників та значним рівнем навантаження. Визначено, що найбільший ризик виникнення професійних захворювань пов'язаний з пилом та статичним навантаженням, а робота в таких умовах призводить до збільшення темпу старіння гірників. Так, при стажеві роботи менше 10-ти років при середньому календарному віці 28.3 років темп старіння склав 7 років, а при стажеві роботи більше 10-ти років цей показник склав близько 9 років. Перевищення біологічного віку над календарним після зміни в середньому становить 15 років.

Наукова новизна. В умовах розробки тонких вугільних пластів встановлено характер взаємозв'язку між комплексом шкідливих факторів, ризиком виникнення професійних захворювань та темпами старіння робітників.

Практична значимість. Для збільшення тривалості життя робітників, задіяних на очисних роботах при розробці тонких вугільних пластів, необхідно переглянути режими роботи й відпочинку та забезпечити їх роботу не більше 4 годин із обов'язковими перервами на відпочинок.

Ключові слова: икідливі виробничі фактори, тонкі вугільні пласти, біологічний вік, гірник, гігієнічні вимоги

\section{АНАЛИЗ ФАКТОРОВ, ВЛИЯЮЩИХ НА СОСТОЯНИЕ ПРОФЕССИОНАЛЬНОГО ЗДОРОВЬЯ И БИОЛОГИЧЕСКОГО ВОЗРАСТА ГОРНЯКОВ ПРИ ПОДЗЕМНОЙ РАЗРАБОТКЕ УГОЛЬНЫХ ПЛАСТОВ}

\section{С. Чеберячко, Ю. Чеберячко, В. Соцков, А. Титов}

Цель. Установление влияния условий труда рабочих горных предприятий при разработке тонких угольных пластов на характер и темп их старения путем определения биологического возраста и оценки величины риска возникновения профессиональных заболеваний.

Методика. Гигиеническую оценку условий труда и величину риска возникновения профессиональных заболеваний определяли по известным нормативным методикам. Для расчета биологического возраста горняков был использован подход, разработанный в Институте геронтологии Академии медицинских наук Украины. 
Общую концентрацию пыли в воздухе горных выработок определяли с помощью аспиратора “АЭРА”. Для оценки функционального состояния человека использована следующая техника: тонометр "Nissei DS-1902” и “Omron M10-IT”, инфракрасный бесконтактный термометр “Мaniquick MQ-160”, весы медицинские "ВМ-150”. Отбор проб в зоне дыхания горняков осуществлялся аналитическими фильтрами “АФА-20”. Обработка результатов исследований проводилась с помощью метода статистического анализа.

Результаты. Установлено превышение предельно допустимых показателей неблагоприятных факторов для горняков - пыли, шума и вибрации. Условия труда характеризуются постоянным неудобным положением тела рабочих и значительным уровнем нагрузки. Определено, что наибольший риск возникновения профессиональных заболеваний связан с пылью и статической нагрузкой, а работа в таких условиях приводит к увеличению темпа старения горняков. Так, при стаже работы не менее 10-ти лет при среднем календарном возрасте 28.3 года темп старения составил 7 лет, а при стаже работы более 10-ти лет этот показатель составил около 9 лет. Превышение биологического возраста над календарным после изменения в среднем составляет 15 лет.

Научная новизна. В условиях разработки тонких угольных пластов установлен характер взаимосвязи между комплексом вредных факторов, риском возникновения профессиональных заболеваний и темпами старения рабочих.

Практическая значимость. Для увеличения продолжительности жизни рабочих, задействованных на очистных работах при разработке тонких угольных пластов, необходимо пересмотреть режимы работы и отдыха и обеспечить их работу не более 4 часов с обязательными перерывами на отдых.

Ключевые слова: вредные производственные факторы, тонкие угольные пласты, биологический возраст, горняк, гигиенические требования

\section{ARTICLE INFO}

Received: 12 February 2018

Accepted: 11 September 2018

Available online: 17 September 2018

\section{ABOUT AUTHORS}

Sergiy Cheberiachko, Doctor of Technical Sciences, Professor of the Department of Aerology and Labour Protection, Dnipro University of Technology, 19 Yavornytskoho Ave., 4/70, 49005, Dnipro, Ukraine. E-mail: cheberiachkoyi@ukr.net

Yurii Cheberiachko, Candidate of Technical Sciences, Associate Professor of the Department of Aerology and Labour Protection, Dnipro University of Technology, 19 Yavornytskoho Ave., 4/70, 49005, Dnipro, Ukraine. E-mail: cheberiachkoyi@ukr.net

Vadym Sotskov, Candidate of Technical Sciences, Associate Professor of the Underground Mining Department, Dnipro University of Technology, 19 Yavornytskoho Ave., 4/60, 49005, Dnipro, Ukraine. E-mail: vadimsockov@gmail.com

Oleksandr Tytov, Candidate of Technical Sciences, Associate Professor of the Department of Mining Machines and Engineering, Dnipro University of Technology, 19 Yavornytskoho Ave., 2/15, 49005, Dnipro, Ukraine. E-mail: alextitovalex77@gmail.com 